\title{
On the Evaluation System of EVA-BSC Business Performance of Listed Companies in Shaanxi Province
}

\author{
Xiaojun Deng \\ College of Accounting and Finance, Xi'an Peihua University, Xi'an, Shaanxi 710125
}

Keywords: EVA-BSC coupling; business performance evaluation; construction; application

\begin{abstract}
Based on the current performance evaluation of the listed companies in Shaanxi Province, the EVA-BSC operating performance evaluation system of listed companies in Shaanxi Province is constructed with consideration of the advantages of EVA financial indicators and BSC non-financial indicators. Prior to it, the EVA financial indicators that reflect the value creation ability of the enterprise and the BSC indicators oriented by the strategic non-financial indicators performance test have been analyzed. This paper conducted an empirical research on the financial performance data of 41 listed companies in Shaanxi Province in 2017, and verified the validity and practical application value of the EVA-BSC business performance evaluation system. It is found that the EVA-BSC business performance rankings of 15 companies are generally consistent with the EVA value rankings, and the rankings of the other 26 companies differed from the EVA value rankings, which, to some extent, proved the EVA-BSC evaluation system's comprehensiveness of the evaluation of business performance, and had a good practical application value.
\end{abstract}

\section{Situation of Performance Evaluation in Shaanxi Listed Companies}

By the end of 2017, there were 46 listed companies in Shaanxi Province, covering various industries ranging from manufacturing, finance, mining, wholesale and retail, tourism, accommodation and catering, publishing and printing, power and gas, to broadcasting and television. Among them, 28 were manufacturing enterprises, accounting for $61 \%$ of the total number of listed companies in Shaanxi Province; 4 mining companies accounted for 8\%. After analyzing the financial reports of 46 listed companies in 2017, it is found that these companies shared some issues in common regarding business performance evaluation. 1. Financial indicator is heavily weighted to maximize profits. The performance evaluation indicators of listed companies in Shaanxi Province mainly include sales net interest rate, return on equity, and profit margin of main business, etc. These financial indicators do not promote to the growth and development of the company. 2. Cost of equity capital has been overlooked. The value created by excessive investment by listed companies in Shaanxi Province is less than the cost of equity capital; 3. There is inadequate attention on non-financial indicators. Although many listed companies in Shaanxi Province began to pay attention to non-financial indicators, they are lopsided with little proportion and subjective, failing to meet the expected performance evaluation goals.

\section{EVA-BSC Based Performance Evaluation System for Shaanxi Listed Companies}

\subsection{Necessity and feasibility of coupling EVA and BSC}

\subsubsection{Realize organic integration of financial and non-financial indicators}

Theoretically, financial indicators and non-financial indicators are important components of corporate performance evaluation system. Only by combining the two can we effectively achieve corporate strategic performance evaluation goals. The traditional financial performance evaluation is generally conducted after the events. The performance data contained in the financial indicators are not significantly related to the strategic objectives of the enterprise. So it is hard to provide a forward-looking approach for the sustainable financial development of the enterprise. As market competition goes increasingly fierce, companies should pay more attention to the increasingly important non-financial factors such as technological innovation, talents, and knowledge to achieve the integration of financial and non-financial indicators. 


\subsubsection{The integration of EVA and BSC is consistent with corporate strategic goals}

EVA regards whether the current business activities of the enterprise create value. The value creation period should be consistent with the company's going concern assumption, which urges operators not to gain short-term benefits at the expense of long-term interests ${ }^{[1]}$. The Balanced Scorecard introduces dimensions such as customer, learning and growth focuses on resources that are conducive to the implementation of corporate strategic objectives, and integrates and then divides financial strategy objectives into small targets, so that financial performance evaluation complements corporate financial strategy objectives at different levels. EVA focuses on shareholder value creation, while BSC focuses on the formulation and implementation of financial strategies. The integration of the two is an objective requirement for sustainable financial value creation.

\subsubsection{Conducive to internal governance of the company}

The listed companies should establish a modern enterprise management system and advanced management ideas, which indicates that listed companies must build and strengthen internal corporate governance. It is the premise of implementing the EVA-BSC business performance evaluation system. What's more, to govern a company, there should be a complete, reasonable and effective corporate governance structure, of which the theoretical basis is the supervision and reward and punishment system. According to the principal-agent theory, only by combining the interests of the company owner and the operator can we keep an order internal management. The Interim Measures for the Performance Evaluation of Central Enterprise Leaders revised in 2016 took EVA as the performance evaluation indicator, in order to supervise and motivate the company's management staff by a more realistic and reliable business performance. The indicator system that integrates the BSC advantage and takes it into the assessment helps strengthen the internal governance of the company while stimulating the enthusiasm of stakeholder value creation.

\subsection{Design Principles of EVA-BSC Business Performance Evaluation System}

\subsubsection{Qualitative and quantitative}

When constructing the EVA-BSC business performance evaluation system, it is necessary to select a large number of quantitative and qualitative indicators which complement each other and form a multi-dimensional performance evaluation system. Therefore, to ensure the efficient operation of this evaluation system, the combination of qualitative and quantitative indicators is the primary principle.

\subsubsection{Comprehensiveness and priority}

In the EVA-BSC business performance evaluation system, indicators need to be selected with the consideration of finance, customer, learning and growth, and internal business processes. If only a few important indicators are selected, sampling bias will ensue. Similarly, selecting all indicators covering all aspects will increase the workload of performance appraisal. Neither can effectively feedback nor improve the financial problems that may exist in the process of enterprise performance evaluation.

\subsubsection{Operability and comparability}

Operability requires the collection and processing of various financial data to be timely and efficient. Therefore, when selecting indicators, it is necessary to ensure that the current information collection and processing means can deal with different financial data in a timely and efficient manner, so as to realize the ultimate goal of performance evaluation. As the performance evaluation of the enterprise is the strategic financial positioning for the sustainable development of the enterprise, the indicators selected should be both measurable and comparable. This comparability includes both the vertical comparison of the indicators at different time points and the horizontal comparison between different companies.

\subsubsection{Dynamic contingency}

The core of enterprise performance evaluation is to ensure efficient information feedback and adjustment when the implementation of strategic financial objectives goes astray, so as to meet the changing business environment. To this end, the enterprise performance evaluation system should be dynamically contingent, with a view to adapting to contingency in the future. 


\subsection{Design of EVA-BSC Business Performance Evaluation System for Listed Companies in Shaanxi Province}

According to the design principle and ideas of performance evaluation system, the Enterprise Performance Evaluation Standard Value 2016 and enterprise business performance evaluation method at home and abroad ${ }^{[2]}$, EVA-BSC based performance evaluation system is structured based on current operation of Shaanxi listed companies as shown in Table 1. It contains EVA and other 12 grade II indicators, and four dimensions, namely, finance, customer, internal process, learning and growth.

Table 1 EVA-BSC Based Performance Evaluation System for Shaanxi Listed Companies

\begin{tabular}{|c|c|c|c|}
\hline Grade I & Grade II & Calculation Formula/Meaning & Source \& Code \\
\hline \multirow[t]{4}{*}{ Finance } & EVA & NOPAT - Cost of Capital & Model Calculation, X1 \\
\hline & EVA Return Rate & EVA / Total Adjusted Capital & Model Calculation, X2 \\
\hline & Return on Total Asset & Net Profit / Average Total Assets & Annual Report, X3 \\
\hline & Return On Equity & Net Profit / Owners Equity & Annual Report, X4 \\
\hline \multirow[t]{2}{*}{ Customer } & Customer Loyalty & $\begin{array}{c}\text { Top Five Customers' Revenue Proportion of } \\
\text { Operating }\end{array}$ & $\begin{array}{c}\text { Substitution } \\
\text { Variables, X5 } \\
\end{array}$ \\
\hline & Sales Increase & $\begin{array}{c}\text { （Current Sales - Last Year's Sales）/Last } \\
\text { Year's Sales }\end{array}$ & Annual Report,X6 \\
\hline \multirow[t]{4}{*}{ Internal Progress } & $\begin{array}{l}\text { Total Asset Turnover } \\
\text { Ratio } \\
\end{array}$ & Net Sales / Average Total Assets & www.cninfo.com.cn, X7 \\
\hline & Inventory Turnover & Annual Cost of Sales / Average Stock Balance & www.cninfo.com.cn,X8 \\
\hline & R\&D Input & R\&D Expenditure / Prime Operating Revenue & Annual Report,X9 \\
\hline & Ratio of Profits to Cost & Total Profit / Total Cost & Annual Report,X10 \\
\hline \multirow[t]{3}{*}{$\begin{array}{l}\text { Learning and } \\
\text { Growth }\end{array}$} & Employee Quality & $\begin{array}{c}\text { College(and above) Educated Employees / } \\
\text { Total Employees }\end{array}$ & Annual Report,X11 \\
\hline & R\&D Ratio & R\&D Employees / Total Employees & Annual Report,X12 \\
\hline & $\begin{array}{l}\text { Per-capita Education } \\
\text { Spending }\end{array}$ & Educational Expenditure / Total Employees & Annual Report,X13 \\
\hline
\end{tabular}

Note: Due to objective reasons including considerable empirical sample, complicated data processing and inaccessible data, this paper brings in top five customers' revenue proportion of operating in place of customer satisfaction ${ }^{[3]}$.

\section{Empirical Examination on EVA-BSC Based Performance Evaluation System for Shaanxi Listed Companies}

\subsection{Sample Selection and Data Sources}

Forty-one Shaanxi listed companies are selected from 46 in Shanghai and Shenzhen Stock Exchanges, without three undesirable ones and two (XINGHUA CHEMISTRY and HST) facing withdrawal risks. Disclosed data of 41 listed companies in 2107 are mainly required from audited Annual Report 2016 and 2017 published on www.cninfo.com.cn. SPSS22.0 serves for data statistics and analysis.

\subsection{Test on the Application of EVA-BSC Business Performance Evaluation System in Sample Enterprises}

Factor analysis is applied to examine the feasibility and interpretability of EVA-BSC based performance evaluation system for 41 sample companies. The method mainly adopts the dimension reduction. By a series of procedure like the principal component adaptability test, factor quantity determination, the factor score and the comprehensive score calculation, the linear relationship between 4 factors and 13 indicators can be obtained with the matrix of the original variable score coefficient corresponding to each factor.

$$
\mathrm{Y} 1=0.303 \mathrm{X} 1+0.307 \mathrm{X} 2+0.272 \mathrm{X} 3+0.262 \mathrm{X} 4+0.109 \mathrm{X} 5-0.006 \mathrm{X} 6+0.051 \mathrm{X} 7-0.045 \mathrm{X} 8+
$$


$\mathrm{Y} 2=-0.187 \mathrm{X} 1-0.045 \mathrm{X} 2+0 \mathrm{X} 3-0.021 \mathrm{X} 4-0.243 \mathrm{X} 5+0.136 \mathrm{X} 6+0.016 \mathrm{X} 7-0.045 \mathrm{X} 8-0.435 \mathrm{X} 9$ $+0.454 \mathrm{X} 10-0.098 \mathrm{X} 11+0.027 \mathrm{X} 12-0.001 \mathrm{X} 13$

$\mathrm{Y} 3=-0.235 \mathrm{X} 1+0.076 \mathrm{X} 2+0.082 \mathrm{X} 3+0.011 \mathrm{X} 4+0.196 \mathrm{X} 5-0.137 \mathrm{X} 6-0.072 \mathrm{X} 7-0.036 \mathrm{X} 8-$ $0.064 X 9+0.123 \times 10+0.485 X 11+0.462 \times 12-0.076 \times 13$

$\mathrm{Y} 4=-0.217 \mathrm{X} 1-0.062 \mathrm{X} 2+0.025 \mathrm{X} 3+0.048 \mathrm{X} 4-0.014 \mathrm{X} 5-0.277 \mathrm{X} 6+0.417 \mathrm{X} 7+0.519 \mathrm{X} 8+$ $0.026 \times 9-0.074 X 10+0.185 \times 11-0.045 X 12-0.238 \times 13$

Combining with data from 41 Shaanxi listed companies in 2017, formulas above work out factor scores, which are then weighted by variance, contribute / aggregate variance to get composite score and performance ranking for 41 companies based on formula $\mathrm{Y}=45.90 \% \mathrm{Y} 1+23.00 \% \mathrm{Y} 2+12.20 \% \mathrm{Y} 3+$ 13.80\% Y4, shown in Table 2.

Table 2 Comprehensive scores and rankings of EVA-BSC operating performance evaluation of 41 listed companies in Shaanxi Province

\begin{tabular}{|c|c|c|c|c|c|}
\hline Company & $\mathrm{Y} 1$ & Y2 & Y3 & Y4 & $\mathrm{Y}$ \\
\hline LONGI & 52847.70 & -32561.28 & -41018.68 & -38094.98 & 4455.68 \\
\hline SHCI & 47394.29 & -29145.24 & -36888.77 & -34695.65 & 3917.71 \\
\hline CHINA XD & 15702.14 & -9636.76 & -12233.70 & -11725.29 & 1268.54 \\
\hline CCOOP & 14316.01 & -8803.81 & -11140.67 & -10449.41 & 1187.96 \\
\hline AECC AVIATION POWER & 13914.20 & -8503.29 & -10895.33 & -10705.25 & 1079.54 \\
\hline CRE & 10005.50 & -6151.52 & -7754.59 & -7297.57 & 836.82 \\
\hline SHAANXI GAS & 6961.82 & -4167.02 & -5573.39 & -6024.84 & 447.01 \\
\hline FIBERHOME ELECTRONICS & 4669.98 & -2809.67 & -3686.33 & -3918.82 & 322.45 \\
\hline HNA-CAISSA TRAVEL & 3730.43 & -2298.01 & -2936.17 & -2592.79 & 320.90 \\
\hline SHAANGU & 5438.04 & -3223.56 & -4387.56 & -4960.11 & 315.49 \\
\hline YCHJ & 4595.15 & -2757.86 & -3650.40 & -3949.40 & 301.98 \\
\hline ZEMIC & 3470.60 & -2082.56 & -2740.80 & -2885.39 & 244.42 \\
\hline ENVIRONMENTAL PROTECTION EQUIPMENT & 2856.98 & -1728.08 & -2229.85 & -2333.96 & 208.28 \\
\hline SHAANXI HEIMAO & 2839.13 & -1715.84 & -2244.15 & -2342.66 & 199.24 \\
\hline SUNRESIN NEW MATERIALS & 1537.28 & -933.70 & -1157.76 & -1143.76 & 133.89 \\
\hline TYPICAL & 1335.78 & -795.15 & -1057.18 & -1179.91 & 85.58 \\
\hline CHENXI AVIATION & 1383.24 & -788.67 & -1055.89 & -1417.31 & 76.31 \\
\hline GLOBAL PRINTING & 636.45 & -368.68 & -506.34 & -631.29 & 33.13 \\
\hline BVEA & 941.61 & -524.31 & -790.13 & -1054.58 & 30.17 \\
\hline SXBN & 485.07 & -280.07 & -383.67 & -499.90 & 23.25 \\
\hline QJCT & 581.66 & -314.21 & -504.17 & -730.55 & 7.18 \\
\hline SHAANXI JINYE & 580.03 & -290.77 & -522.79 & -886.80 & -12.94 \\
\hline GINWA & -321.33 & 195.56 & 266.99 & 250.15 & -22.07 \\
\hline BUT'ONE & -81.39 & 56.44 & 63.80 & -130.18 & -31.37 \\
\hline TIANHE DEFENSE & -35.14 & 36.28 & -2.04 & -249.37 & -42.55 \\
\hline INTERNATIONAL MEDICAL INVESTMENT & 376.86 & -161.08 & -387.13 & -811.30 & -42.62 \\
\hline
\end{tabular}




\begin{tabular}{|c|c|c|c|c|c|}
\hline \multicolumn{6}{|c|}{ Cont. to Table 2} \\
\hline DAGANG ROAD MACHINERY & -99.63 & 105.73 & 44.50 & -351.35 & -62.24 \\
\hline WESTERN METAL MATERIALS & 582.65 & -253.74 & -594.16 & -1278.30 & -69.52 \\
\hline XI'AN CATERING & -788.71 & 513.58 & 576.15 & 391.91 & -90.71 \\
\hline XI'AN TOURISM & -1024.25 & 657.13 & 768.22 & 539.00 & -112.47 \\
\hline J\&R OPTIMUM ENERGY & -1935.09 & 1268.55 & 1445.55 & 1237.42 & -177.04 \\
\hline TONG OIL TOOLS & -1913.52 & 1219.09 & 1446.40 & 927.59 & -221.13 \\
\hline BAOTI & -2977.66 & 1856.79 & 2295.10 & 1923.58 & -279.47 \\
\hline QINCHUAN MACHINE TOOL & -3241.69 & 2035.74 & 2471.64 & 2028.79 & -314.62 \\
\hline AEROSPACE POWER & -3441.29 & 2153.03 & 2644.85 & 2220.28 & -323.04 \\
\hline BODE ENERGY EQUIPMENT & -3910.65 & 2463.01 & 3014.68 & 2460.97 & -370.36 \\
\hline LIGEANCE AEROSPACE & -2804.04 & 1452.05 & 2085.97 & 1595.22 & -374.16 \\
\hline AVIC AIRCRAFT & -3904.05 & 2478.66 & 2944.81 & 2147.45 & -419.01 \\
\hline SCMC & 2970.01 & -1088.97 & -3418.07 & -7784.86 & -549.45 \\
\hline CDD & -6866.45 & 4214.92 & 5267.87 & 4507.59 & -654.15 \\
\hline JDCMOLY & -17107.64 & 10625.88 & 13174.92 & 11681.22 & -1530.36 \\
\hline
\end{tabular}

\section{Conclusion}

It can be seen from Table 2 that the overall ranking of these enterprise performance is consistent with the EVA value ranking, confirming the central role of EVA in the financial dimension of the EVA-BSC business performance evaluation system. Therefore, EVA as a performance evaluation indicator can effectively measure business performance. In addition, the difference between EVA and comprehensive score ranking is very small. Only a few companies have gotten inconsistent rankings. For example, in 2012, there were differences in the rankings of EVA and comprehensive scores of China Fiberhome Electronics, Tongyuan Petroleum, Baoguang, and SHAANXI BROADCAST \& TV NETWORK INTERMEDIARY co., ltd. This, to a certain extent, affirms the comprehensiveness of the EVA-BSC business performance evaluation system for the evaluation of the business operation industry. The effectiveness of the EVA-BSC business performance evaluation system performance evaluation is summarized through empirical research. It can be seen that the listed companies in Shaanxi Province still prefer financial indicators in the process of performance evaluation. The EVA-BSC business performance evaluation system has not been applied reasonably and effectively. This is because of the demanding of high level management in the evaluation system, and more importantly, the owners and operators do not show much interest in the system. In view of this, the listed companies in Shaanxi Province should analyze the internal and external advantages and disadvantages of themselves, and make improvements on the system with consideration of their strategic objectives, factors such as the life cycle of the enterprise and the output-output ratio of performance management, etc., so as to realize scientific performance evaluation of listed companies in different industries in Shaanxi Province.

\section{Reference}

[1]S·David·Young, Stephen·F·O’ Byrne. EVA and Value-Based Management [M]. Beijing: Social Sciences Academic Press (CHINA), 2002 
[2]Mousui Modak, K hanindra Pathak, Kunal Kanti Ghosh. Performance evaluation of out sourcing decision using a BSC and Fuzzy AHP approach: A case of the Indian coalmining organization [J]. Resources Policy, 2017.

[3]Zhang Rui, Yu Haiyan. Overview of Enterprise Management Performance Evaluation: Theory, Method and Prospect [J]. Contemporary Finance \& Economics, 2016(11):106-116. 